\title{
Chemical profile and in vivo hypoglycemic effects of Syzygium jambos, Costus speciosus and Tapeinochilos ananassae plant extracts used as diabetes adjuvants in Puerto Rico
}

Jannette Gavillán-Suárez ${ }^{1,2+}$, Alexandra Aguilar-Perez ${ }^{3}$, Natalie Rivera-Ortiz ${ }^{2}$, Karla Rodríguez-Tirado ${ }^{4}$, Wanda Figueroa-Cuilan ${ }^{5}$, Lorelein Morales-Santiago ${ }^{2}$, Gerónimo Maldonado-Martínez ${ }^{6}$, Luis A. Cubano ${ }^{7}$ and Michelle M. Martínez-Montemayor ${ }^{3^{*}+}$

\begin{abstract}
Background: The increasing numbers of people who use plant-based remedies as alternative or complementary medicine call for the validation of less known herbal formulations used to treat their ailments. Since Puerto Rico has the highest rate of Type 2 diabetes within all the states and territories of the United States, and Puerto Ricans commonly use plants as diabetes adjuvants, it is important to study the plants' physiological effects, and identify their bioactive compounds to understand their role in modulation of blood glucose levels. We present the phytochemical profiles and hypoglycemic effects of Tapeinochilus ananassae, Costus speciosus and Syzygium jambos.

Methods: Phytochemicals in methanolic and aqueous extracts were analyzed by thin layer chromatography (TLC). Alkaloids (Bromocresol green, $\lambda=470 \mathrm{~nm}$ ), flavonoids ( $\mathrm{AlCl}_{3}, \lambda=415 \mathrm{~nm}$ ), saponins (DNS, $\lambda=760 \mathrm{~nm}$ ), tannins $\left(\mathrm{FeCl}_{3} / \mathrm{K}_{4} \mathrm{Fe}(\mathrm{CN})_{6}, \lambda=395 \mathrm{~nm}\right.$ ) and phenolics (Folin-Ciocalteau, $\lambda=765 \mathrm{~nm}$ ) were quantified. Male C57BLKS/J (db/db) and C57BL/J (ob/ob) genetically obese mice were orally gavaged with aqueous extracts of lyophilized plant decoctions for 10 wks.

Results: Our results show that $T$. ananassae had significantly greater amounts of flavonoids and tannins, while $S$. jambos showed the greatest concentration of phenolics and C. speciosus exhibited higher amounts of alkaloids. C57BLKS/J $d b / d b$ treated with plant extracts show better glucose modulation when the extracts are administered in complement with an insulin injection. Finally, C57BL/J ob/ob mice on T. ananassae and S. jambos treatments show better blood glucose modulation over time.
\end{abstract}

Conclusion: These results document for the first time the chemical profile of T. ananassae and provide evidence for a potential anti-diabetic efficacy of T. ananassae and S. jambos.

Keywords: Diabetes adjuvants, C57BLKS/J db/db and C57BL/J ob/ob mice, Chemical profile, Syzygium jambos, Tapeinochilus ananassae, Costus speciosus

\footnotetext{
* Correspondence: michelle.martinez@uccaribe.edu

${ }^{\dagger}$ Equal contributors

${ }^{3}$ Department of Biochemistry, Universidad Central del Caribe-School of

Medicine, P.O. Box 60327, Bayamón 00960-6032, Puerto Rico

Full list of author information is available at the end of the article
} 


\section{Background}

The widespread use of medicinal plants to mitigate or cure medical conditions such as diabetes calls for their scientific investigation. According to the Annual Survey by the Centers for Disease Control and Prevention (CDC) in Atlanta; since 1996, Puerto Rico has the highest Type 2 diabetes rate within the United States in individuals 18 years or older [1, 2]. After conducting an ethnopharmacological survey in 11 municipalities of southeast Puerto Rico and carrying out a literature review about herbal remedies used to manage hyperglycemia, we identified that people living in the southeast rural region of Puerto Rico frequently use four medicinal plants as alternative or complementary treatments for diabetes: Costus speciosus (J. Koening) Sm. (Zingiberaceae), Syzygium jambos (L.) Alston (Myrtaceae), Tradescantia spathacea and Tapeinochilos ananassae K. Schum. (Zingiberaceae) [3-5]. In vitro studies using these plants to screen their activities as inhibitors of processes related to the physiopathology (oxidative stress, protein glycosylation and aldose reductase activity) of diabetes (data not shown) led us to perform chemical profiling and functional in vivo studies of C. speciosus, S. jambos and T. ananassae.

C. speciosus, a small plant with scarlet flowers, commonly known as "insulin" in Puerto Rico, is a plant widely used in indigenous systems of medicine for the treatment of various ailments. C. speciosus rhizomes are used as an alternative source for diosgenin, and also to control diabetes due to the antidiabetic, antilipidemic and antioxidant effects of its compounds including sesquiterpene lactones [6-8]. $S$. jambos, "rose apple", is an ornamental fruit tree from Southeast Asia that is also found in tropical regions. This medicinal plant is used to treat diabetes, inflammation, and gastrointestinal disorders [9, 10]. Diabetic animals treated with aqueous and ethanolic extracts from the seeds of $S$. jambos show reduced glycemic effect [11]. S. jambos leaf and fruit extracts contain high concentrations of tannins and phenolic acids, respectively $[12,13]$. Another plant commonly referred to as "insulin" by populations of southeast Puerto Rico is $T$. ananassae, an ornamental garden plant native to Malasia, Indonesia, New Guinea and Australia. There are no previous studies describing $T$. ananassae's phytochemical profile or anti-diabetic activity, although we previously reported that this plant is currently being used as a herbal remedy for diabetes in the southeast region of Puerto Rico [5].

The beneficial effects of diverse groups of phytochemicals in herbal remedies have been related to activities consistent with their potential use in treating diabetic disorders and complications. The in vivo anti-diabetic activity of plant extracts has been correlated with their flavonoid and total phenolic content $[14,15]$. Glycosides, flavonoids, tannins and alkaloids have shown reliable activities that may be useful for the treatment of Type 2 diabetes [16]. Also saponins, such as oleanolic acid, exhibit hypoglycemic activity and resveratrol, a phenolic compound, shows insulin-like effects in streptozotocininduced diabetic rats $[17,18]$. In the case of tannins, two modes of action have been proposed to explain their anti-diabetic potential. At the protein level, tannins act via insulin receptor activation leading to an increase in glucose uptake rate and lower glucose levels. At the molecular level, tannins have significant superoxide scavenging and antioxidant activity [19]. These facts are relevant since high levels of superoxide ions in pancreatic $\beta$-cells, block insulin signaling, affecting glucose regulation [20].

Although the traditional use of decoctions of C. speciosus and $S$. jambos has been reported as both complementary and alternative treatments for diabetes, the antidiabetic effects of the decoctions of these plants, including $T$. ananassae have not been validated in animal models. Consequently, this report presents the results of in vivo studies using C57BLKS/J $d b / d b$ and C57BLKS/J $o b / o b$ genetic diabetes animal models. Moreover, we present the systematic characterization of major phytochemicals and potential markers of anti-diabetic activity in the plant aqueous extracts.

\section{Methods}

\section{Chemicals and reagents}

Folin-Ciocalteu reagent, HPLC grade methanol, tannic acid ACS reagent, Quillaja saponin, 3,5-dinitrosalicilic acid (98\%), aluminum trichloride, sulfuric acid (18 M), glucose (99.5\%), stigmasterol (95\%), hydroquinone (99\%), ursolic acid (98.5 \%), digitoxin (92\%) and bromocresol green (95\%) were obtained from Sigma-Aldrich (St. Louis, MO, USA). Quercetin dihydrate (98\%) and dragendorff's reagent were obtained from Aldrich (Milwaukee, WI, USA). Ferric Chloride $\left(\mathrm{FeCl}_{3} \cdot 6 \mathrm{H}_{2} \mathrm{O}\right)(97.0-102.0 \%)$ was obtained from Spectrum Chemical and Lab Products (Gardena, California, USA) and potassium ferrocyanide $\left(\mathrm{K}_{4} \mathrm{Fe}(\mathrm{CN})_{6} \cdot 3 \mathrm{H}_{2} \mathrm{O}\right), \mathrm{HCl}$ $(12 \mathrm{M})$, sodium hydrogen phosphate, ethyl acetate (EtOac), acetic anhydride and dichloromethane were obtained from Thermo Fisher Scientific (New Jersey, USA). Nicotine (99\%) was obtained from VWR (New Jersey, USA). All chemicals were used without further purification.

\section{Ethnopharmacological survey}

The questionnaire used in the ethnopharmacological survey in Puerto Rico was adapted from the one published by TRAMIL Network (www.tramil.net). The second section of the questionnaire follows a structured interview, asking participants to provide information 
about the botanical remedies used by the family as the first treatment for the ailments included in the survey. Open-ended questions were used to obtain a detailed description of the health problem, treatment preparation, application and results obtained, including dosage and contraindications or side effects for adults and children. Plants having a usage frequency of $20 \%$ or more for a particular ailment were selected for the in vitro or in vivo studies. The Institutional Review Board at the University of Puerto Rico-Cayey approved the questionnaire used for the survey and the informed consent forms. After completing the survey and reviewing the ethnobotanical literature for herbal remedies used for their hypoglycemic effects, medicinal plants used as diabetes adjuvants were identified [3-5].

\section{Plant collection and identification}

Leaves of C. speciosus, S. jambos and T. ananassae were collected in Puerto Rico. Vouchers of Costus specious (019660), Tapeinochilus ananassae (019553), Syzygium jambos (019663) were numbered and deposited at the George Proctor Herbarium (SJ) in Puerto Rico. José Sustache, Botanist and Head of the PR Department of Natural and Environmental Resources classified the botanical species.

\section{Preparation of decoctions, methanolic and aqueous extracts}

For in vitro and quantitative analysis, fresh leaves (50 g) were weighed, freeze-dried using a Freezone 4.5 lyophilizer and extracted overnight with methanol $(\mathrm{MeOH})(350 \mathrm{~mL})$ using a Soxhlet apparatus. The resulting extracts were concentrated to dryness by rotatory evaporation (Yamato RE200 ) at room temperature to yield from $1-11 \%$ w/w of extract (1-5 g extract/ $45-200 \mathrm{~g}$ fresh leaves). Stock solutions of dry plant extracts were re-dissolved in various solvents (depending on the phytochemical to be tested). Alternatively, for the preparation of decoctions used in in vitro, in vivo and quantitative analysis, fresh leaves (30 g) were boiled in $100 \mathrm{~mL}$ of distilled, deionized water, concentrated to $15 \mathrm{~mL}$, to lyophilize $3 \times 5 \mathrm{~mL}$ replicates, filtered through cheesecloth and freeze-dried. The resulting solids were re-dissolved in $\mathrm{ddH}_{2} \mathrm{O}$ and used to prepare aqueous extracts of known concentrations. All extracts were filtered using a $0.4 \mu \mathrm{m}$ Nanopure ${ }^{\ominus}$ filter syringe before assayed [21].

\section{Dosage calculation}

A tea of C. speciosus leaves was prepared according to a consensus of dosage and administration reported during the TRAMIL interviews from Puerto Ricans who selfmedicate with this medicinal plant [5]. The preparation consisted of boiling $18.00 \mathrm{~g}$ of fresh leaves (six medium size leaves) in $1.89 \mathrm{~L}$ of $\mathrm{ddH}_{2} \mathrm{O}$ for $15 \mathrm{~min}$. The resulting extract was filtered through cheesecloth and aliquots of
5-10 mL were freeze-dried to calculate the total solids. The $\% \mathrm{w} / \mathrm{w}$ yield was $6.6 \%$, which corresponds to $1.14 \mathrm{~g}$ of total solids in $1.89 \mathrm{~L}$. According to the survey the daily dosage of the tea is $250 \mathrm{~mL}(8 \mathrm{oz})$ or $158.3 \mathrm{mg}$ of tea solids. Assuming an average body weight of $70 \mathrm{Kg}$, the dose of tea solids per $\mathrm{Kg}$ of body weight is $2.3 \mathrm{mg} /$ $\mathrm{kg}$ BW, which was the dose used as reference for preparing the remaining teas and used in all in vivo studies.

\section{Chromatographic separation and qualitative analysis}

Thin layer chromatography was performed using $10 \times$ $10 \mathrm{~cm}, 0.2 \mathrm{~mm}$ Nano-silica gel 60 HPTLC plates (Supelco, PA). Lyophilized methanolic and aqueous extracts were dissolved in methanol or methanol:water, respectively according to procedures described previously [22-24]. The following solvent systems and visualization techniques were used to obtain the phytochemical profile as alkaloids (dichloromethane $\left(\mathrm{CH}_{2} \mathrm{Cl}_{2}\right): \mathrm{MeOH}(15: 1) ; 254 \mathrm{~nm}$ and visible with Dragendorff's reagent), cardiac glycosides (EtOAc:MeOH:water (20:2.5:2.5); $366 \mathrm{~nm}$ after spraying with sulphuric acid), phenolics $\left(\mathrm{CH}_{2} \mathrm{Cl}_{2}\right.$ :EtOAc: glacial acetic acid (5:4:1); visible with Folin-Ciocalteu's reagent and heating), saponins $\left(\mathrm{CH}_{2} \mathrm{Cl}_{2}\right.$ :glacial acetic acid:MeOH:water (16:8.5:3:2); $366 \mathrm{~nm}$ and visible light with anisaldehydesulphuric acid reagent), sterols $\left(\mathrm{CH}_{2} \mathrm{Cl}_{2}\right.$ :glacial acetic acid:$\mathrm{MeOH}$ :water (32:17:6:4); visible light with $\mathrm{FeCl}_{3}$ :acetic acid:sulfuric acid solution and heating), tannins, hydrolysable tannins, flavonoids and terpenoids (EtOAc:toluene:acetic acid (8:4:1); 254, $366 \mathrm{~nm}$ and visible with anisaldehyde-sulphuric acid reagent and heating). Appropiate standards were used for each class of phytochemicals (Table 1). The fluorescence of each spot was noted and Rf values were determined.

\section{Quantitative phytochemical analysis}

Total phenolic content (TPC) in methanolic and aqueous extracts dissolved in DMSO was determined using Folin-Ciocalteu method $(765 \mathrm{~nm})$ with some modifications, while flavonoids in methanolic extracts were determined by the aluminum chloride method $(415 \mathrm{~nm})$ using quercetin as standard, as described by [25]. The bromocresol green method [26] and the Prussian Blue reaction [27] were used to quantify total alkaloids $(470 \mathrm{~nm})$ and tannins $(395 \mathrm{~nm})$ in methanolic and aqueous extracts using nicotine and tannic acid as standards, respectively. Saponins were determined by the dinitrosalicylic acid (DNS) method $(540 \mathrm{~nm})$ as reported previously $[17,28]$.

\section{Animals}

Study 1

Male BKS.Cg-Dock7m +/+ Leprdb/J (C57BLKS/J db/db) 5 wks old mice (Jackson Laboratories, ME) were maintained under a constant 12-h light:12-h dark cycle with a 
Table 1 Phytochemical analysis by TLC of plant extracts ${ }^{a}$

\begin{tabular}{|c|c|c|c|c|c|c|c|c|}
\hline \multirow[t]{2}{*}{ Plant extract } & \multicolumn{8}{|c|}{ Phytochemicals (Visible and UV fluorescence) } \\
\hline & $\begin{array}{l}\text { Flavonoids } \\
\text { (orange, yellow) }\end{array}$ & $\begin{array}{l}\text { Alkaloids } \\
\text { (pink-orange) }\end{array}$ & $\begin{array}{l}\text { Phenolics } \\
\text { (dark blue) }\end{array}$ & $\begin{array}{l}\text { Saponins } \\
\text { (orange) }\end{array}$ & $\begin{array}{l}\text { Sterols } \\
\text { (purple) }\end{array}$ & Terpenoids (violet-pink) & $\begin{array}{l}\text { Cardiac glycosides } \\
\text { (orange) }\end{array}$ & $\begin{array}{l}\text { Tannins } \\
\text { (beige) }\end{array}$ \\
\hline T. ananassae (met) & $0.34,0.41,0.48$ & $\begin{array}{l}0.21,0.30 \\
0.69,0.84\end{array}$ & $0.21,0.54,0.81$ & 0.93 & $0.78,0.91$ & 0.18 & 0.92 & ND \\
\hline S. jambos (met) & $0.33,0.37$ & $\begin{array}{l}0.15,0.25 \\
0.31,0.38\end{array}$ & $\begin{array}{l}0.11,0.33,0.38 \\
0.43,0.54,0.56 \\
0.64,0.70,0.84 \\
0.90\end{array}$ & $0.36,0.92$ & $0.86,0.95$ & 0.05 & 0.91 & 0.79 \\
\hline C. speciosus (met) & ND & $\begin{array}{l}0.04,0.32 \\
0.50,0.56 \\
0.63,0.73 \\
0.81\end{array}$ & $0.62,0.78,0.89$ & 0.96 & $0.85,0.94$ & 0.14 & 0.91 & 0.78 \\
\hline T. ananassae (aq) & - & ND & 0.36 & 0.67 & - & ND & - & $0.10-0.17^{d}$ \\
\hline S. jambos (aq) & - & ND & $0.06,0.70-0.80$ & $\begin{array}{l}0.36,0.52, \\
0.89\end{array}$ & 0.94 & - & - & ND \\
\hline C. speciosus (aq) & $\begin{array}{l}0.44-0.55^{c} \\
0.51-0.59\end{array}$ & ND & $0.06,0.09,0.20$ & 0.66 & 0.95 & ND & - & ND \\
\hline
\end{tabular}

${ }^{\mathrm{a}} \mathrm{Rf}$ values reported as the means of two chromatograms; ${ }^{\mathrm{b}}$ Standards: Quercetine $(0.12$, yellow-orange), Caffeine (0.55, light pink) and Nicotine (0.34, light pink), Hydroquinone (0.09, dark blue), Commercial saponin (0.28, orange), Stigmasterol (0.97, purple) and Ursolic acid (0.15, violet-pink), Digitoxin (0.75, orange), Tannic Acid $\left(0.06\right.$, beige); ${ }^{c}$ Yellow at $366 \mathrm{~nm}$; ${ }^{d}$ Yellow at $254 \mathrm{~nm}$; ND Not detected

temperature of $22-24{ }^{\circ} \mathrm{C}$. Four to five animals per cage were divided into 12 treatment groups, for a total of 50 mice. The mice had free access to NIH\#31 M Rodent Diet pellets (Agricultural Exports Inc., Doylestown, PA) and water. Consumption of food and water were monitored daily. Mice were weighed weekly for 10 wks.

\section{Study 2}

Male B6.Cg-Lepob/J (C57BL/J ob/ob), 5 wk old mice (Jackson Laboratories, ME) were maintained as those described in Study 1. Three to four animals per cage were divided into 4 treatment groups $(n=11$ or 12 per treatment). The Institutional Animal Care and Use Committees at Universidad Central del Caribe-School of Medicine approved the protocols for Studies 1 and 2 .

\section{Treatment administration}

\section{Study 1}

$d b / d b$ mice were orally gavaged daily for 10 wks with control (sterile water) or $0.2,2.2,22 \mathrm{mg} / \mathrm{kg} \_\mathrm{BW}$ ) in a $100 \mu \mathrm{L}$ volume of $T$. ananassae, C. speciosus and $S$. jambos aqueous extracts or $220 \mathrm{mg} / \mathrm{kg} \_\mathrm{BW}$ in a $100 \mu \mathrm{L}$ volume of T. ananassae, and C. speciosus aqueous extracts, for a total of 12 treatments.

\section{Study 2}

$o b / o b$ mice were orally gavaged daily for 10 wks with control (sterile water) or $2.2 \mathrm{mg} / \mathrm{kg} \_\mathrm{BW}$ in a $100 \mu \mathrm{L}$ volume of $T$. ananassae, C. speciosus and $S$. jambos aqueous extracts.

\section{Glucose tolerance test (IP-GTT)}

IP-GTT was performed after a $12-\mathrm{h}$ fast as depicted in Fig. 1. A $10 \%$ glucose solution was injected i.p. $(1 \mathrm{mg} / \mathrm{g}$ $\mathrm{BW}$ ) and blood samples were obtained from the tail vein at $0,15,30,60,90$, and $120 \mathrm{~min}$ after glucose administration as in [29]. Mice were tail bled at 0 wks (before treatment intervention), at $5 \mathrm{wks}$ and at $10 \mathrm{wks}$ (end of the study). Blood glucose was determined using a glucometer (Optium EZ, Abbot Laboratories and One Touch Ultra Mini, Johnson and Johnson) via test strips. Limit of detection of Optium EZ is $500 \mathrm{mg} / \mathrm{dL}$ (used in Study 1) and of One Touch Ultra Mini is $600 \mathrm{mg} / \mathrm{dL}$ (used in Study 1 and 2).

\section{Insulin tolerance test (IP-ITT)}

IP-ITT was performed at the end of the study to determine the effects of insulin on blood glucose modulation between control and treatment groups as depicted in Fig. 1. The $d b / d b$ mice become severely diabetic by 4 wks of age as described by Buchanan [30] thus we used an insulin (Humulin R U-500, Lilly, Indianapolis, IN) dose of 8 units/g BW to achieve adequate glucose lowering. Mice were fasted (12-h), on a different day than that of the IP-GTT; they were tail bled pre-injection and then glucose concentrations were determined at $15,30,60,90$, and 120 min post-injection as by Keller et al. [29].

\section{Plasma insulin detection}

Plasma insulin levels were analyzed using the Ultrasensitive Mouse Insulin ELISA Kit (Crystal Chem Inc., IL) 


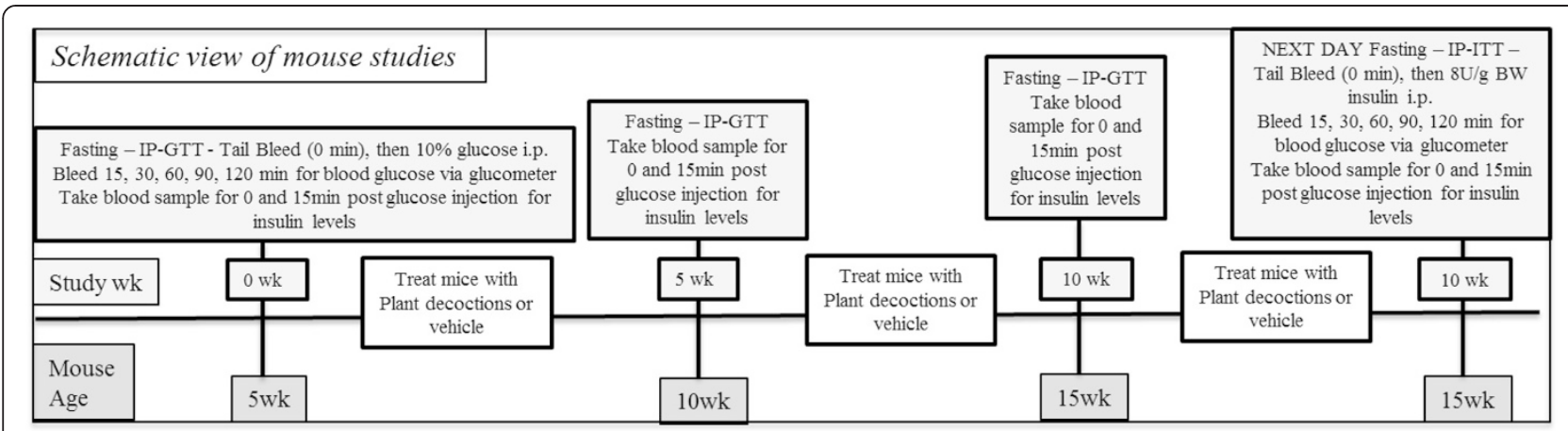

Fig. 1 Schematic drawing of in vivo experimental procedures. In study 1 and study 2, the mice (5 wks old) were randomly assigned to the various experimental treatments that were administered daily for 10 wks. An IP-GTT was performed at 0,5 and 10 wks of the study, while an IP-ITT was performed at $10 \mathrm{wks}$. In each intervention blood was collected at 0 and $15 \mathrm{~min}$ post injection to detect insulin plasma levels

following manufacturer's instructions for the wide range analysis. Five microliters of sample were used; the assay was conducted in duplicates. For Study 1 we used plasma samples collected at 10 wks of control and of $S$. jambos treated mice at a concentration of $2.2 \mathrm{mg} /$ kg_BW at the IP-GTT and IP-ITT at 0 or $15 \mathrm{~min}$ after glucose or insulin injection, respectively (see Fig. 1). For study 2 we used plasma samples collected at 10 wks of $S$. jambos and T. ananassae treated mice compared to controls at the IP-GTT and IP-ITT at 0 or $15 \mathrm{~min}$ after glucose or insulin injection, respectively (see Fig. 1). The plates were read using the Glomax Multi Detection System (Promega, WI) at an absorbance of $450 \mathrm{~nm}$.

\section{Statistical analysis}

All in vitro tests were performed in triplicate. Results are expressed as means \pm standard error of the mean. The concentrations of phytochemicals obtained from the quantitative analyses were estimated from the leastsquares regression lines $\left(\mathrm{r}^{2} 98.99-1.00 \%\right)$. In vitro statistical analyses were done using GraphPad Prism version 5.0b (San Diego, CA). The data were analyzed using regular one-way analysis of variance procedures. Values $P<0.05$ were considered significant. For in vivo studies, to assess the behavior of all the variables in our models, a normality diagnostic was performed. A multivariate analysis was conducted, in particular; a repeated measures ANOVA model was constructed in order to establish the statistical association between the dependent variables and each study variable. A Mauchly's test of sphericity was performed to assess if our models had or not the assumption of compound symmetry. If nonsignificant, we report the univariate results with an Epsilon correction; if significant, we report the multivariate results using the Pillai's Trace estimator. Either of the last explained results was used to evaluate the time effect in our models. A test of Between-Subjects Effect with a Pairwise Comparisons (Bonferroni's or Dunnett's adjustment for multiple comparisons) was applied to perceive statistical differences between and within the groups. The analyses were constructed using a general to specific approach as follows: analysis WHOLE, where we confronted all weeks ( 0,5 \& 10 altogether), analysis at 0,5 and at 10 wks. The sub-measures were $0,15,30$, 60, 90, 120 min. Finally; we constructed various plots to help illustrate the changes over time of our studied groups. Due to the exponential nature and intrinsic unstable behavior of the dependent variable (blood glucose levels) over time, a percent change transformation was made in the form of $\% \Delta=$ New Value - Old Value /(ABS) Old Value $\times 100$. Therefore, if the original value increases, the percent change decreases and vice versa. The significance level $(\alpha)$ was set to $\leq 0.05$. The statistical software for in vivo analysis used was Statistical Package for Social Sciences (SPSS, Chicago, IL) v.17.0 for Windows.

\section{Results}

Profile of surveyed population using medicinal plants

Table 2 shows the profile of the surveyed population that uses herbal remedies as the first treatment for the ailments assessed during the ethnopharmacological survey. A total of 10 out of 118 (8.5\%) families in the study population reported using herbal remedies for diabetes as alternative or complementary treatments. The median

Table 2 Profile of surveyed population using medicinal plants

\begin{tabular}{ll}
\hline IndicatorNariable & Results \\
\hline $\begin{array}{l}\text { Use of herbal remedies for } \\
\text { diabetes }\end{array}$ & $10 / 118$ families (8.5\%) \\
Median age of women & 51.1 years \pm 16.7 years \\
Education and marital status & $70 \%$ college education and married \\
Employment status & $50 \%$ employed \\
Frequency of reported treatments & $55 \%$ once/surveyed population \\
\hline
\end{tabular}


age of the women who reported the use of medicinal plants for diabetes was 51.1 years ( \pm 16.7 years). The majority of the participants reported to have college education and being married (70 \% in both cases). Roughly, half of the study population that uses medicinal plants for diabetes reported being employed. Nine different plant remedies were used among the study population the last time that one of the family members was treated for diabetes. The more frequent descriptions of diabetes as a health problem were uncontrolled sugar levels (high or low) and dizziness. Other descriptions included dry mouth, excessive thirst, sleepiness, restlessness, not feeling the legs, blindness or poor vision and frequent urination. About half of the treatments were reported once $(55 \%)$ and the use was classified as not significant according to TRAMIL methodology [31]. Most of the plants $(60 \%)$ were obtained at the store or market. Decoction of fresh leaves was the most frequent mode of preparation of the herbal remedies. Dosages were variable, with most families reporting the use of one cup of tea (decoction) daily or during one week. The herbal remedies prepared from Costus speciosus (J. Koening) $\mathrm{Sm}$. (Zingiberaceae) and Tapeinochilos ananassae K. Schum. (Zingiberaceae) were selected for the present study as their use was significant according to TRAMIL and they are commonly known as "insulin" in the studied population.

\section{Major groups of phytochemicals were found in plant extracts}

To establish product integrity during the scientific investigation of complex botanical products, the National Institutes of Health (NIH), National Center for Complementary and Integrative Health (NCCIH) has published guidelines that required the characterization (chemical profile or fingerprint) and identification of relevant marker compounds used for standardization [32]. Qualitative TLC analysis of methanolic and aqueous extracts of the leaves of $S$. jambos, $T$. ananassae and $C$. speciosus showed the presence of flavonoids, alkaloids, phenolic compounds, saponins, terpenoids, tannins and cardiac glycosides (Table 1). Aqueous extracts showed fewer phytochemicals than methanolic extracts. TLC analysis confirmed the presence of a significant number of phenolics in $S$. jambos methanolic and aqueous extracts, alkaloids in C. speciosus methanolic extracts, flavonoids in T. ananassae methanolic extracts and $C$. speciosus aqueous extracts, and tannins in $T$. ananassae aqueous extracts. The results for the quantitative analysis of the extracts presented in Table 3, confirms the qualitative chemical profile and shows a significant concentration of phenolics in S. jambos ( $0.45 \mathrm{mg} \mathrm{QE} / \mathrm{mg}$ extract), flavonoids and tannins in $T$. ananassae $(24.3 \mathrm{mg} \mathrm{QE} / \mathrm{g} \mathrm{DW}$ and $3.361 \mathrm{mg}$ Tannic acid/g FW, respectively) and alkaloids in C. speciosus dry or fresh leaves $(806.0 \% \mu \mathrm{g}$ Nicotine/mg FW).

\section{Plant extracts do not affect weight gain, food or water intake in C57BLKS/J ( $d b / d b)$ and C57BL/J (ob/ob) mice}

In Study 1, three out of the 50 mice died from causes unrelated to treatment toxicity or to an unsuccessful gavage. Results show that there is no significant effect of treatment on weight gain, average food or water intake throughout the 10 wks of the study, an indication that the extracts were not toxic to mice (Additional file 1: Figure S1). In Study 2, none of the $o b / o b$ mice died and there was no significant effect of treatments on weight gain, or on average food or water intake. (Additional file 2: Figure S2). Interestingly, overall $d b$ / $d b$ mice weighed less, and consumed more water than $o b / o b$ mice.

\section{Plant decoctions modulate C57BLKS/J ( $d b / d b)$ mice blood glucose levels when administered in complement to insulin}

Blood glucose levels (BGL) were monitored in mice treated with plant extracts or control (total of 12 treatments) at 5 and 10 wks post-treatment. In Study 1, there was no significant effect of treatments in lowering blood glucose levels at 5 or 10 wks post-treatment. At 5 wks, S. jambos treated mice showed better blood glucose modulation compared to the mice receiving other plant extract treatments (Fig. 2a-d). Mice on $C$. speciosus 22 (BGL $273 \mathrm{mg} / \mathrm{dL}$ ), and $220 \mathrm{mg} / \mathrm{kg}$ B BW (BGL $211 \mathrm{mg} / \mathrm{dL}$ ) had lower baseline BGL compared to vehicle treated mice. After the glucose injection, most of the animals treated with C. speciosus $2.2 \mathrm{mg} / \mathrm{kg}$ B BW

Table 3 Quantitative analysis of plant extracts

\begin{tabular}{|c|c|c|c|c|c|c|c|}
\hline \multirow[t]{2}{*}{$\begin{array}{l}\text { Plant } \\
\text { Extract }\end{array}$} & \multirow[t]{2}{*}{$\begin{array}{l}\text { Flavonoids } \\
( \pm \text { SD mg QE/g DW) }\end{array}$} & \multicolumn{2}{|c|}{$\begin{array}{l}\text { Total Phenolic Content } \\
( \pm \text { SD mg QE/mg extract) }\end{array}$} & \multirow[t]{2}{*}{$\begin{array}{l}\text { Tannin Content ( } \pm \text { mg } \\
\text { Tannic acid eq/g FW) }\end{array}$} & \multirow[t]{2}{*}{$\begin{array}{l}\text { Saponins ( } \pm \text { SD \% mg } \\
\text { Quillaja/mg DW }\end{array}$} & \multicolumn{2}{|c|}{$\begin{array}{l}\text { Alkaloids ( } \pm \text { SD \% } \mu \mathrm{g} \\
\text { Nicotine eq/mg FW) }\end{array}$} \\
\hline & & Methanolic & Aqueous & & & Methanolic & Aqueous \\
\hline S.jambos & $24.3 \pm 1.3^{\mathrm{a}}$ & $0.45 \pm 0.09^{a}$ & $0.18 \pm 0.04^{a}$ & $3.361 \pm 0.004^{a}$ & $0.6 \pm 0.3$ & $\mathrm{nd}^{\mathrm{a}}$ & $1.80 \pm 0.10^{a}$ \\
\hline T. ananasse & $29.8 \pm 0.0^{b}$ & $0.14 \pm 0.02^{b}$ & $0.034 \pm 0.005^{b}$ & $10.337 \pm 0.008^{b}$ & $0.4 \pm 0.4$ & $6.90 \pm 0.17^{b}$ & $5.20 \pm 0.43^{b}$ \\
\hline C. speciosus & $15.8 \pm 0.9^{c}$ & $0.35 \pm 0.01^{a}$ & $0.060 \pm 0.002^{c}$ & $1.516 \pm 0.008^{c}$ & $0.2 \pm 0.3$ & $806.0 \pm 172.0^{c}$ & $3.49 \pm 0.15^{c}$ \\
\hline
\end{tabular}

$N D$ Not detected. Values are mean \pm SD. Different letters show significant differences, $P<0.05$ 

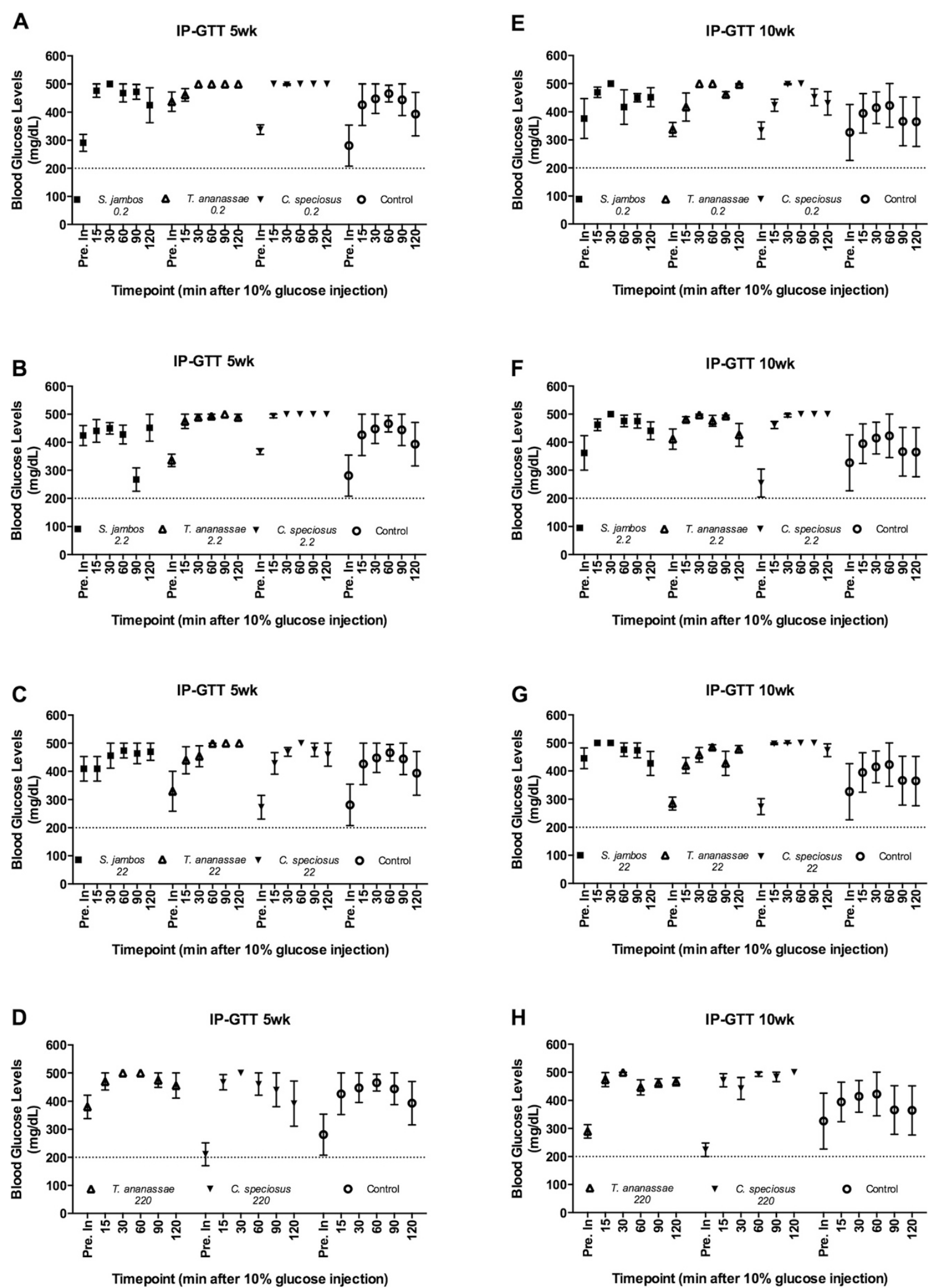

Fig. 2 (See legend on next page.) 
(See figure on previous page.)

Fig. 2 IP-Glucose Tolerance Test (IP-GTT) in the C57BLKS/J (db/db) mouse model. A-D. IP-GTT performed at 5 wks post-treatment with

(a) $0.2 \mathrm{mg} / \mathrm{kg} \_B W,(\mathbf{b}) 2.2 \mathrm{mg} / \mathrm{kg} \_B W$, (c) $22 \mathrm{mg} / \mathrm{kg} \_$BW of S. jambos, T. ananassae, C. speciosus aqueous extracts or water (control), (d) $220 \mathrm{mg} / \mathrm{kg} \_$BW

of T. ananassae, C. speciosus aqueous extracts or water (control). E-H. IP-GTT performed at 10 wks - post-treatment with (e) 0.2 mg/kg_BW,

(f) $2.2 \mathrm{mg} / \mathrm{kg}$ _BW, (g) $22 \mathrm{mg} / \mathrm{kg}$ _BW of S. jambos, T. ananassae, C. speciosus aqueous extracts or water (control), (h) $220 \mathrm{mg} / \mathrm{kg}$ _BW of T.

ananassae, C. speciosus aqueous extracts or water (control). Horizontal dashed line is set at $200 \mathrm{mg} / \mathrm{dL}$. Mean values of BGL before (Pre inj.)

and after 15, 30, 60, 90 and 120 min of an IP $10 \%$ glucose solution injection. Values are means \pm SEM, $n=4-5 / g r o u p$

had glucose levels greater than $500 \mathrm{mg} / \mathrm{dL}$ and were not able to reduce their BGL to basal state, indicating that glucose tolerance in these mice is impaired (Fig. 2b). Moreover, mice that received C. speciosus $220 \mathrm{mg} / \mathrm{kg} B \mathrm{BW}$, tended to show lower BGL (BGL $392 \mathrm{mg} / \mathrm{dL}$ ) when compared to the animals on the control treatment at the last reading (120 $\mathrm{min}, \mathrm{BGL} 467 \mathrm{mg} / \mathrm{dL}$ ). Interestingly, mice treated with $S$. jambos $2.2 \mathrm{mg} / \mathrm{kg}$ showed decreased BGL at $90 \mathrm{~min}$ (BGL $267 \mathrm{mg} / \mathrm{dL}$ ) post injection. These results suggest that mice receiving $2.2 \mathrm{mg} / \mathrm{dL}$ of $S$. jambos display gradual blood glucose modulation (increased and decreased) peaks. At $10 \mathrm{wks}$, baseline BGL of mice on $C$. speciosus 2.2, 22, $220 \mathrm{mg} / \mathrm{kg}$ BW, and $T$. ananassae $2.2 \mathrm{mg} / \mathrm{kg} \_B W$ were lower compared to control mice (Fig. 2e-h). Furthermore, at $60 \mathrm{~min}$ post-glucose mice on all $S$. jambos treatments had lower blood glucose levels compared to $C$. speciosus mice, and by $120 \mathrm{~min}$, all of the glucose readings for $T$. ananassae and $S$. jambos mice were below the limit of detection of the glucometer (500 mg/dL). Interestingly, after $15 \mathrm{~min}$ of glucose administration plasma insulin levels were significantly higher $(P$ $<0.05$ ) in both control and $S$. jambos $2.2 \mathrm{mg} / \mathrm{kg}$ BW treated mice at 10 wks post-treatment (Fig. 5a). The IPITT data showed that baseline BGL for all mice were in a range from BGL 325 to $491 \mathrm{mg} / \mathrm{dL}$ (Fig. 3a-d). By $60 \mathrm{~min}$ most of the treated mice showed a drop in BGL where the lowest blood glucose value obtained was BGL $159 \mathrm{mg} / \mathrm{dL}$ (S. jambos $0.2 \mathrm{mg} / \mathrm{kg}$ BW), followed by BGL $167 \mathrm{mg} / \mathrm{dL}$ (C. speciosus $22 \mathrm{mg} / \mathrm{kg} B \mathrm{BW})$, and BGL $177 \mathrm{mg} / \mathrm{dL}$ (T. ananassae $22 \mathrm{mg} / \mathrm{kg} \mathrm{BW})$. The remaining plant treated and control (BGL $245 \mathrm{mg} / \mathrm{dL}$ ) mice had values greater than $200 \mathrm{mg} / \mathrm{dL}$ at $60 \mathrm{~min}$, while at $120 \mathrm{~min}$ the lowest BGL were $122 \mathrm{mg} / \mathrm{dL}$ (C. speciosus $22 \mathrm{mg} / \mathrm{kg} B \mathrm{BW}$ ), followed by BGL $146 \mathrm{mg} / \mathrm{dL}$ (T. ananassae $2.2 \mathrm{mg} / \mathrm{kg} B W$ ). The remaining mice displayed BGL over $200 \mathrm{mg} / \mathrm{dL}$; however mice treated with C. speciosus $220 \mathrm{mg} / \mathrm{kg} B \mathrm{BW}$, and $S$. jambos 0.2 and $22 \mathrm{mg} / \mathrm{kg}$ BW displayed lower values than those of the control mice (BGL $252 \mathrm{mg} / \mathrm{dL}$ ) at $120 \mathrm{~min}$ post-injection. Plasma insulin levels for the control and $S$. jambos $2.2 \mathrm{mg} / \mathrm{kg}$ BW were similarly affected during the IP-ITT after the insulin injection (Fig. 5b).

\section{T. ananassae (5 wks) and S. jambos (5 and 10 wks) significantly reduce $\mathrm{BGL}$ in $o b / o b$ mice}

There were differences in blood sugar level modulation in $o b / o b$ mice treated with different plant extracts. At
5 wks, the $T$. ananassae $(P<0.006)$ and $S$. jambos $(P<$ $0.049)$ treated mice were significantly more efficient in modulating the effects of the glucose compared to control or C. speciosus treated mice (Fig. 4a). All of the plant treated mice had lower baseline blood glucose levels $(S$. jambos BGL $297 \mathrm{mg} / \mathrm{dL}$, T. ananassae BGL $262 \mathrm{mg} / \mathrm{dL}$, C. speciosus BGL $337 \mathrm{mg} / \mathrm{dL}$ ) compared to vehicle (BGL $402 \mathrm{mg} / \mathrm{dL}$ ) treated mice. Moreover, at $10 \mathrm{wks}, S$. jambos $(P<0.056)$ treated mice were more efficient in modulating blood glucose levels when compared with control or mice treated with the remaining plant extracts (Fig. 4b). The baseline blood glucose of $S$. jambos mice was lower (BGL $208 \mathrm{mg} / \mathrm{dL}$ ) overall. Upon injection of glucose, $S$. jambos treated mice displayed overall lower peaks in blood glucose. There were no differences in the levels of plasma insulin in response to a glucose injection in control, T. ananassae or S. jambos treated mice (Fig. 5c). In Study 2, the IP-ITT test blood glucose baseline values were lower than in Study 1 and ranged from BGL 221 to $292 \mathrm{mg} / \mathrm{dL}$. By $60 \mathrm{~min}$ post-injection glucose concentrations were similar in $S$. jambos (BGL $99 \mathrm{mg} / \mathrm{dL}$ ) and control (BGL $91 \mathrm{mg} / \mathrm{dL}$ ) groups. In addition, at $120 \mathrm{~min}$ BGL remained at non-diabetic levels $(<200 \mathrm{mg} / \mathrm{dL})$. These values were $\mathrm{BGL} 78 \mathrm{mg} / \mathrm{dL}$ (control), BGL $88 \mathrm{mg} / \mathrm{dL}$ (C. speciosus), BGL $107 \mathrm{mg} / \mathrm{dL}$ (T. ananassae) and BGL $92 \mathrm{mg} / \mathrm{dL}$ (S. jambos). Importantly, plasma insulin levels were significantly higher $(P<0.02)$ after the insulin injection in mice regardless of treatment (Fig. 5d).

\section{Discussion}

Globally, as of 2013, an estimated 382 million people have diabetes. In 2012 and 2013 diabetes resulted in 1.5 to 5.1 million deaths per year, making it the 8 th leading cause of death worldwide [33]. Diabetes was the third cause $(10 \%)$ of deaths in 2010 in Puerto Rico, highlighting the importance of diabetes as a health problem in the Island [34]. Interestingly, traditional medicine users in Puerto Rico rely on the use of herbs to lower blood glucose levels [5]. Thus, in an effort to validate the traditional use of these herbs associated with diabetes management and treatment, we undertook an ethnopharmacological approach to screen commonly used but less studied herbal remedies, their biological activities and possible bioactive compounds. Plant extracts were qualitatively screened 

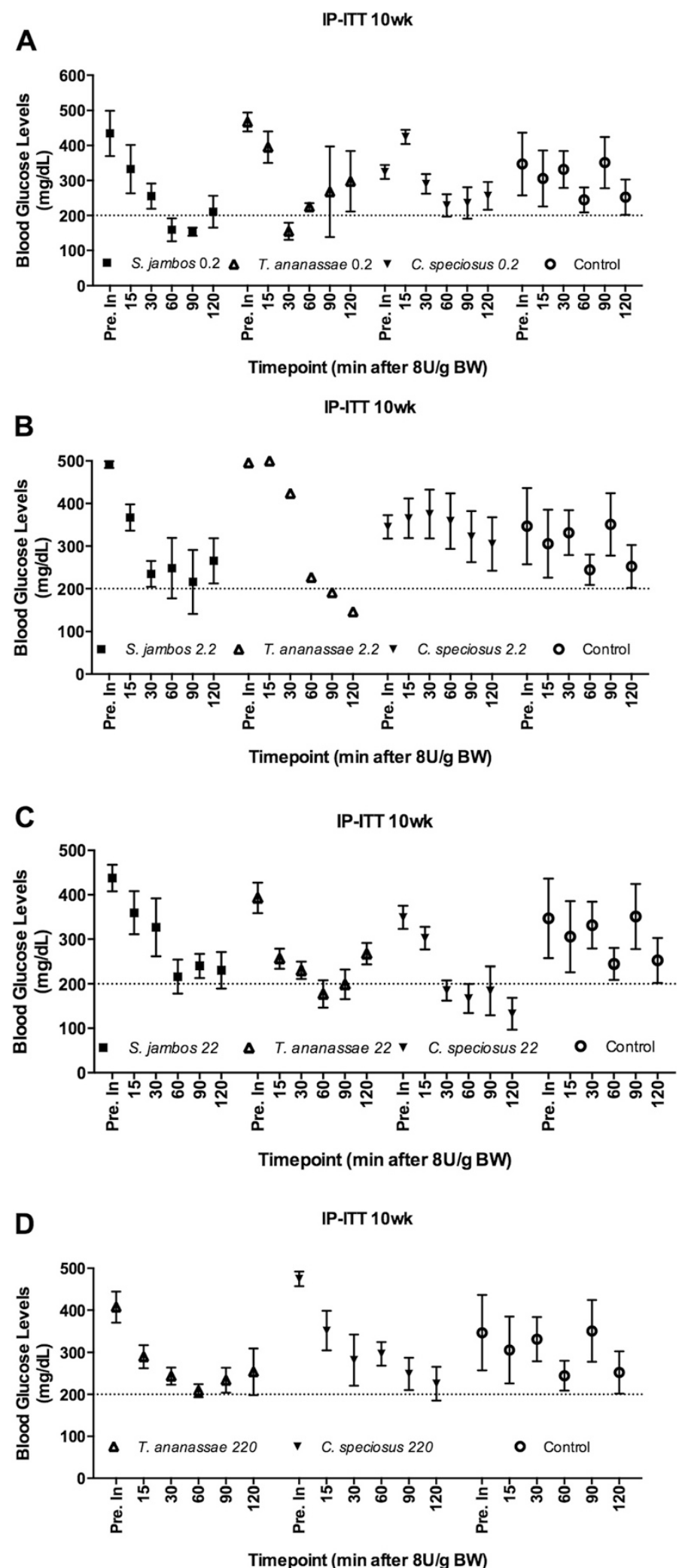

Fig. 3 (See legend on next page.) 
(See figure on previous page.)

Fig. 3 IP-Insulin Tolerance Test (IP-ITT) in the C57BLKS/J (db/db) mouse model. a-d IP-ITT performed at 10 wks - post-treatment with $0.2 \mathrm{mg} / \mathrm{kg} \_B W$ (a), 2.2 mg/kg_BW (b), 22 mg/kg_BW of S. jambos, T. ananassae, C. speciosus aqueous extracts or water (control) (c), 220 mg/kg_BW (d) of T. ananassae, C. speciosus aqueous extracts or water (control). Horizontal dashed line is set at $200 \mathrm{mg} / \mathrm{dL}$. Mean values of BGL before (Pre inj.) and after 15, 30, 60, 90 and 120 min of an IP insulin (8U/g BW) injection. Values are means $\pm S E M, n=4-5 / g r o u p$
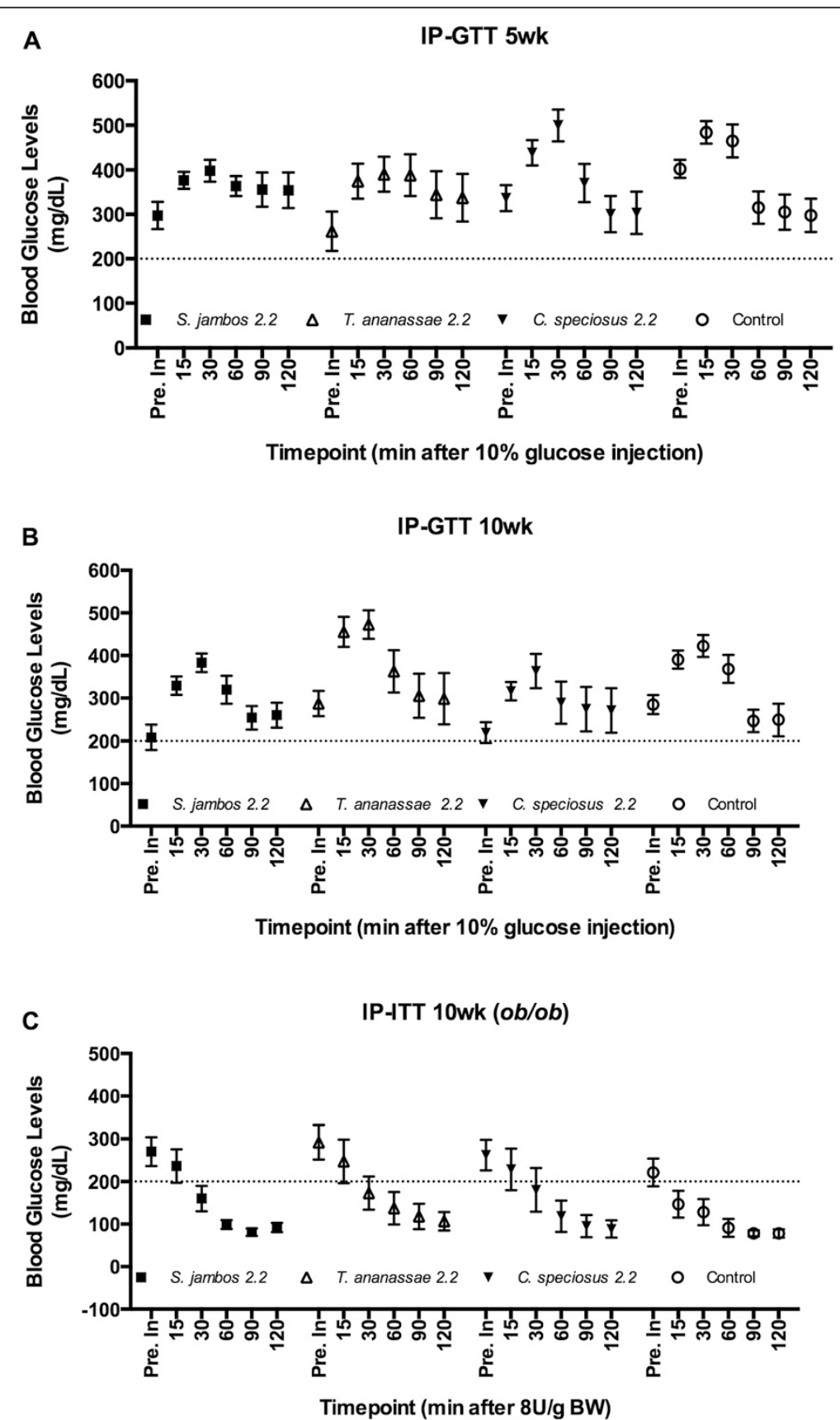

Fig. $4 \mathrm{IP}-\mathrm{GTT}$ and IP-ITT in the C57BL/J (ob/ob) mouse model. A-C. IP-GTT performed at 5 wks (a) and 10 wks (b, c) post-treatment with $2.2 \mathrm{mg} / \mathrm{kg}$ of S. jambos, T. ananassae, C. speciosus aqueous extracts or water (control). Horizontal dashed line is set at $200 \mathrm{mg} / \mathrm{dL}$. Mean values of blood glucose levels before (Pre inj.) and after 15, 30, 60, 90 and 120 min of an IP $10 \%$ glucose solution (a, b) or insulin (8U/g BW) (c) injection. Values are means \pm SEM, n (Control, C. speciosus, T. ananassae) $=11$ group, n (S. jambos) $=12 /$ group 
A

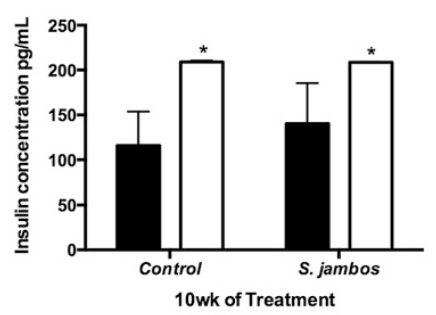

C

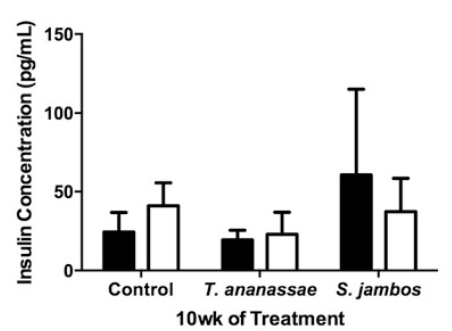

B

IP-ITT $d b / d b$ mice

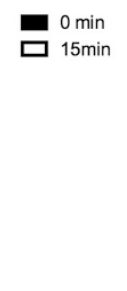

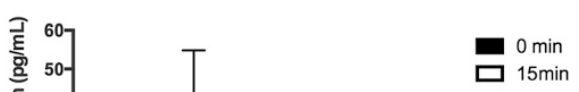

을

$40-$
$30-$
$20-$
0

D

IP-ITT ob/ob mice
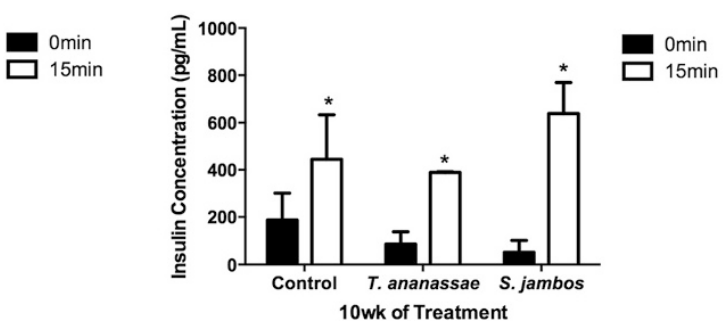

Fig. 5 Plasma insulin levels of mice treated with plant decoctions. a Plasma insulin levels of $d b / d b$ mice before (0 min) and after (15 min) a $10 \%$ glucose injection 10 wks post-treatment with water (Control) or 2.2 mg/kg_BW S. jambos, aqueous extracts. b Plasma insulin levels of $d b / d b$ mice before $(0 \mathrm{~min})$ and after $(15 \mathrm{~min})$ a $8 \mathrm{U} / \mathrm{g}$ BW insulin injection 10 wks post-treatment with water (Control) or $2.2 \mathrm{mg} / \mathrm{kg} \_B W$ S. jambos, aqueous extracts. c Plasma insulin levels of ob/ob mice before $(0 \mathrm{~min})$ and after $(15 \mathrm{~min})$ a $10 \%$ glucose injection 10 wks post-treatment with water (Control) or $2.2 \mathrm{mg} / \mathrm{kg}$ BBW S. jambos or T. ananassae, aqueous extracts. d Plasma insulin levels of ob/ob mice before (0 min) and after (15 min) a $8 \mathrm{U} / \mathrm{g}$ BW insulin injection 10 wks post-treatment with water (Control) or 2.2 mg/kg_BW S. jambos or T. ananassae, aqueous extracts. Columns represent means \pm SEM. Differences are significant when ${ }^{*} P<0.05$

by thin layer chromatography (TLC), while flavonoids, phenolics, saponins, tannins and alkaloids were quantified. We also assessed biological activities in vivo using two genetic diabetes models.

Our results show that $S$. jambos aqueous extract had significantly higher concentrations of phenolic compounds relative to T. ananassae and C. speciosus. Phenolics can be classified into phenolic acids (hydroxycinammic acids, phenylpropanoids), flavonoid polyphenolics (flavonoids), and non-flavonoid polyphenolics (tannins). Plant polyphenols are powerful antioxidants that exert their effects either by scavenging reactive oxygen and nitrogen species, or by functioning as chain-breaking peroxyl radical scavengers [35, 36]. Growing evidence shows that excess generation of reactive free radicals, largely due to hyperglycemia, causes oxidative stress in pancreatic $\beta$-cells, which further exacerbates the development and progression of diabetes and its complications [37]. Reynertson and collaborators analysis of tropical edible fruits by HPLC-PDA showed that ellagic acid and derivatives were the most abundant phenolic compounds in the methanol-formic acid lyophilized extracts of $S$. jambos fruits [13]. This phenolic compound along with t-cinnamic acid, a phenolic acid found in cinnamon bark, accounted for most of the Total Phenolic Content and antiradical activity of the extracts [38]. Also, several ellagitannins were detected in plant extracts of $S$. jambos from Japan and flavonoids have been isolated from aqueous, methanolic and ethanolic extracts of $S$. jambos leaves among which myricetin and quercetin $3-O-\beta-D-x y l o p y r a n o s y l(1-2)-\alpha-$ L-rhamnopiranoside showed potent anti-inflammatory activity [12]. Although we did not find other published studies that reference the in vivo hypoglycemic activity of aqueous extracts of $S$. jambos leaves, an infusion of the leaves of $S$. jambos/S. cumini was tested for its antidiabetic activity by a glucose tolerance test in a randomized, parallel, double-blind clinical trial in non-diabetic and diabetic subjects, with no significant effect in blood glucose levels $[39,40]$. S. cumini plus placebo tablets, placebo tea plus glyburide tablets ( $5 \mathrm{mg}$ twice a day), or placebo tea plus placebo tablets were evaluated in these studies. The authors used two different botanical species indistinctively to prepare the teas, thus the activities reported for each botanical species is uncertain. Moreover, S. cumini has been thoroughly studied at doses similar to the ones reported in this study for its hypoglycemic, antioxidant and antihyperlipidaemic activities, among others [16, 41]. Again, the pharmacological activities of $S$. cumini have been attributed mainly to the presence of flavonoids and phenolics.

Our studies show that $T$. ananassae had higher concentrations of flavonoids and tannins compared to S. jambos 
and C. speciosus extracts. Among the phenolic compounds, the flavonoids, besides functioning as antioxidants, also act as insulin secretagogues that may improve glucose uptake in peripheral tissues. In addition, flavonoids may regulate the activity or expression of rate-limiting enzymes involved in carbohydrate metabolism pathways [42]. Tannins are also phenolic compounds of higher molecular weight commonly used as healing agents. In Ayurveda formulations tannin-rich plants are used for the treatment of diarrhea, while other studies showed that tannins enhance glucose uptake and inhibit adipogenesis [24]. Finally, $C$. speciosus extracts showed a greater amount of alkaloids when compared to $T$. ananassae and $S$. jambos. This could explain the toxicity of $C$. speciosus teas reported in ethnobotanical accounts [4]. Alkaloid fractions have shown beneficial effects in treating hypercholesterolemic, hypertriglyceridemic, hyperlipidemic and/or dyslipidemic conditions and their related complications linked to metabolic disorders such as obesity and diabetes [43]. Phytochemicals reported from $C$. speciosus and other species of the genus Costus that have shown hypoglycemic activity and increased plasma insulin concentrations in alloxaninduced diabetic rats include Quercetine glycosides and the pentacyclic triterpene $\beta$-Amyrin $[44,45]$. An extract of C. speciosus was reported to reduce blood glucose concentrations of streptozotocin-induced hyperglycemic rats. A methanolic extract of dried Costus afer Ker Gawl also reduced blood glucose concentrations in streptozotocin induced hyperglycemic rats, stimulating glucose transport in adipocyte cells, suggesting an ability to improve glucose uptake in vivo [29].

In the current study, we present the differential effects of $S$. jambos, T. ananassae or C. speciosus aqueous plant decoctions on glucose levels of two different genetic mouse models of type- 2 diabetes. Our first mouse study assessed the efficacy of the plant extracts using a mouse model [C57BLKS/J $(d b / d b)]$ that develops hyperglycemia as young as 6 wks of age [30]. Concentrations of the plant extracts in teas administered to mice were evaluated at a dose smaller $\left(0.2 \mathrm{mg} / \mathrm{kg} \_\mathrm{BW}\right)$ and commonly consumed by humans $(2.2 \mathrm{mg} / \mathrm{kg} B \mathrm{BW})$, and at 10 (22 mg/kg_BW) and $100\left(220 \mathrm{mg} / \mathrm{kg} \_\mathrm{BW}\right)$ times greater the concentration used by humans. Our results show that the plant extracts do not affect the weight, food or water intake of $d b / d b$ mice. The glucose peak in nondiabetic individuals rises within one hour of food consumption, but after two hours, blood glucose returns to baseline levels. However, in people with diabetes the glucose peak is higher and it takes longer to decline back to baseline levels upon food consumption. Importantly, studies describe that the experimental basal BGL limit for diabetic animals is $200 \mathrm{mg} / \mathrm{dL}[8,46]$. Herein we show a severe hyperglycemic animal model where BGL drop to values lower than $200 \mathrm{mg} / \mathrm{dL}$ after administration of plant decoctions. Insulin tolerance tests show that mice gavaged with all of the doses of $S$. jambos (0.2, 2.2 and $22 \mathrm{mg} / \mathrm{kg} \_\mathrm{BW}$ ), the higher doses of C. speciosus (22 and $\left.220 \mathrm{mg} / \mathrm{kg} \_\mathrm{BW}\right)$, and one dose of $T$. ananassae $(2.2 \mathrm{mg} /$ kg_BW) plant extracts tend to modulate glucose better as compared to controls. This suggests that the effect these plants exert in the $d b / d b$ mouse model can be complementary to conventional therapy (insulin injection), rather than when administered as alternative therapy (extract administration alone). Moreover, our data shows that plasma insulin levels are significantly higher after the insulin injection. Since the increase of plasma insulin levels occurs regardless of treatment, it is possible that the mechanistic reason for obtaining lower blood glucose levels in response to $S$. jambos treatment in this mouse model is not due to increases in insulin secretion but to other mechanisms such as lower gluconeogenesis or better glucose uptake by sensitive tissues such as liver, muscle, and adipose tissue. It is known that a balance between insulin secretion and insulin action maintains normal glucose tolerance [47]. The lack of statistical significance of blood glucose modulation in Study 1 could be attributed to the small sample size and to the mouse model chosen. The C57BLKS/J $(d b / d b)$ model is obese via a mutation in the leptin receptor, develops insulin resistance very quickly and has progressive $\beta$-cell depletion [29]. This mouse model is commonly used to detect effects of test products in the preservation of $\beta$ cell or insulin resistance.

Since in Study 1 we wanted to test a wide range of doses with various plant extracts, the sample size used per treatment was smaller that the one in Study 2. Previous to conducting mouse Study 2, we carried out a statistical power analysis to assess the sample size needed to detect changes in blood glucose taking into account the variability in blood glucose values obtained in Study 1. In Study 2 we used the C57BL/J (ob/ob) Type-2 diabetes mouse model. This model is also genetically obese but the mutation lies in the production of leptin [48, 49]. The C57BL/J $(o b / o b)$ mice show tendencies in better modulation of euglycemia due to a robust and persistent compensatory pancreatic $\beta$-cell response, matching the insulin resistance with hyperinsulinemia. Studies with $o b / o b$ mice show that at 4 and 8 wks of age these mice have not developed hyperglycemia [50]. In Study 2, we show that plant extracts, especially $T$. ananassae and $S$. jambos, lowered glucose peaks and kept these glucose peaks stable over the $10 \mathrm{wks}$ trial. In healthy people, blood glucose levels are stable, with the exception of the increased level after meals. Lowering peaks and maintaining stable glucose levels demonstrate the capacity of the body to break glucose, secrete insulin and uptake glucose efficiently. Studies also show that by 15 wks the $o b / o b$ mice develop hyperglycemia [30, 50]. In contrast to Study 1, in Study 2 mice treated with the plant 
extracts or controls have stable non-diabetic glucose values (200 $\mathrm{mg} / \mathrm{dL}$ or less) at $60 \mathrm{~min}$ following an i.p. insulin injection. Also, ob/ob mice show plasma insulin levels that are 20 times greater than those detected in $d b / d b$ mice. These results suggest that in the $o b / o b$ mice model we are detecting both endogenous and injected insulin levels at the time the IP-ITT was performed. The $o b / o b$ mice show mild hyperglycemia that is apparent from 8 to 12 wks of age. At this point, pancreatic $\beta$-cell compensation occurs and increased insulin levels are secreted for glucose homeostasis [51]. Our results suggest that the insulin injected is responsible for lowering blood glucose levels in the $o b / o b$ mice and not the plant extract. These results differ from that observed in the insulin resistant model. Potential explanations as to why the plant decoctions resulted in mild modulation of BGL include the severity of the insulin resistance associated with these particular animal models. In addition, contrary to other studies that show anti-diabetic efficacy of plant extracts $[8,39,40,46,52]$ our study aimed to mimic the effects of using traditional remedies by the local Puerto Rican population instead of detecting the activities of these compounds extracted by organic solvents of different polarities [53].

\section{Conclusions}

Our results are the first to show the qualitative and quantitative chemical profile of three commonly used plants by the Puerto Rican population to lower BGL. This report documents for the first time, the in vivo mouse studies and the identification and quantification of phenolic compounds, flavonoids, tannins, alkaloids and saponins in $T$. ananassae plant extracts. Moreover, we document a detailed protocol that was used to detect these compounds. Out of the three plants extracts, S. jambos shows better in vivo efficacy in lowering BGL, when evaluated in diabetes genetic mouse models $(d b / d b)$. At 5 wks, individual mouse BGL readings show that depending on the timepoint either none $(90 \mathrm{~min})$, or only one or two animals have BGL $>500 \mathrm{mg} / \mathrm{dL}$. These data substantiate our results that show that $S$. jambos at levels consumed by humans $(2.2 \mathrm{mg} / \mathrm{kg})$ tends to modulate BGL better than the rest of the plants. Future studies will evaluate the efficacy of these extracts as complementary therapy. Studies will investigate blood glucose modulation when the extracts are administered in addition to other glucose modulators. Our results demonstrate that in an insulin resistant model $(d b / d b)$ when the extracts are used with insulin (complementary therapy), the plant extracts tend to modulate glucose better than controls, while in $o b / o b$ mice this effect is not seen. In some cases, we see that lower doses in complement with insulin have better glucose modulation than the same plant at higher doses (C. speciosus $22 \mathrm{vs.}$ C. speciosus 220). It is possible that the plant extracts display a synergistic or additive effect with insulin that is lost by increasing its concentrations. However, without performing proper combinatorial index analysis [54-56], we cannot be certain that such effects indeed occur. Furthermore, the study reveals that herbal remedies used as diabetes adjuvants contain anti-diabetic drug principles that require further characterization and studies to assess mode of action to provide a rich source for new drug discovery.

\section{Additional files}

Additional file 1: Average food, water intake, and weekly weights in the C57BLKS/J $(d b / d b)$ mouse model. Mice orally gavaged with 0.2 $\mathrm{mg} / \mathrm{kg} \_B W(a), 2.2 \mathrm{mg} / \mathrm{kg} \_B W\left(\right.$ b), $22 \mathrm{mg} / \mathrm{kg} \_B W$ (c) or $220 \mathrm{mg} / \mathrm{kg} \_B W$ (d) of S. jambos, T. ananassae, C. speciosus or Control for 10 wks were weighed weekly. Mice feed and water were measured daily over 10 wks. Values are mean +/- SEM, $n=4$-5/group.

Additional file 2: Average food, water intake, and weekly weights in the C57BL/J (ob/ob) mouse model. Mice orally gavaged with 2.2 $\mathrm{mg} / \mathrm{kg} \_$BW of S. jambos, T. ananassae, C. speciosus or Control for $10 \mathrm{wks}$ were weighed weekly (a). Mice feed (b) and water (c) were measured daily over 10wks. Values are mean $+/$ - SEM, $n=11-12 /$ group.

\section{Abbreviations}

BGL: Blood glucose levels; GTT: Glucose tolerance test; ITT: Insulin tolerance test; TRAMIL: Traditional medicine in the Islands; wks: Weeks.

\section{Competing interests}

The authors state no competing interests are associated with the present study.

\section{Authors' contributions}

JGS, NRO, LMS, KRT, WFC and MMMM participated in research design. AAP, NRO, LMS, KRT, WFC, JGS and MMMM conducted experiments. LAC, MMMM and JGS contributed new reagents or analytic tools. AAP, NRO, LMS, KRT, WFC, GMM, JGS and MMMM performed data analysis. AAP, GMM, LAC, JGS and MMMM wrote or contributed to the writing of the manuscript. All the authors approved and reviewed the final draft of the manuscript.

\section{Acknowledgments}

We would like to express our utmost gratitude to Dr. Raysa Rosario-Acevedo, Mercedes Y. Lacourt-Ventura, Mary Chely Quiñonez and Isabel Colon-Rivera for conducting part of the experiments, and of the data analysis. We thank Dr. Misty Eaton for reading the manuscript, helpful advice and suggestions. We would like to acknowledge the UCC-SOM RCMI Animal Resource Center, the UCC-SOM RCMI Common Instrumentation Area and the NIH-RISE Undergraduate Research Program at UPR-Cayey. This work was conducted with support from the Institute of Interdisciplinary Research at UPR-Cayey, National Institutes of Health/Research Infrastructure in Minority Institutions (RIMI) Program Grant \#1P2MD 001112-0 to UPR-Cayey, and National Center for Research Resources (5G12 RR 003035-27) and the National Institute on Minority Health and Health Disparities (8G12 MD 007583-27) from the National Institutes of Health to UCC-SOM, Title V PPOHA US Department of Education Grant \#P031M105050 to UCC.

\section{Author details}

${ }^{1}$ Institute of Interdisciplinary Research, University of Puerto Rico at Cayey, PO Box 372230, Cayey 00737-2230, Puerto Rico. ²Department of Chemistry, University of Puerto Rico at Cayey, PO Box 372230, Cayey 00737-2230, Puerto Rico. ${ }^{3}$ Department of Biochemistry, Universidad Central del Caribe-School of Medicine, P.O. Box 60327, Bayamón 00960-6032, Puerto Rico. ${ }^{4}$ Present address: University of Puerto Rico Medical Sciences Campus, PO Box 365067, San Juan 00936-5067, Puerto Rico. ${ }^{5}$ Present address: University of 
Missouri-Columbia, Division of Biological Sciences, 110 Tucker Hall, Columbia, MO 65211-7400, USA. ${ }^{6}$ Data Management \& Statistical Research Support Unit, Universidad Central del Caribe-School of Medicine, P.O. Box 60327, Bayamón 00960-6032, Puerto Rico. 'Department of Anatomy and Cell Biology, Universidad Central del Caribe-School of Medicine, P.O. Box 60327, Bayamón 00960-6032, Puerto Rico.

\section{Received: 6 February 2015 Accepted: 8 July 2015 Published online: 22 July 2015}

\section{References}

1. Geiss LS LY, Kirtland K, Barker L, Burrows NR, Gregg EW. National Diabetes Surveillance System. Atlanta, GA: Div of Diabetes Translation, National Center for Chronic Disease Prevention and Health Promotion, CDC; 2012.

2. Centers for Disease Control and Prevention. Increasing Prevalence of Diagnosed Diabetes — United States and Puerto Rico, 1995-2010. MMWR. 2012;61:918-21.

3. Nuñez E: Plantas Medicinales de Puerto Rico. Río Piedras: Editorial de la Universidad de Puerto Rico; 1989

4. Benedetti M. Sembrando y sanando en Puerto Rico. 1st ed. Verde Luz: Puerto Rico; 1996.

5. Alvarado-Guzman JA, Gavillan-Suarez J, Germosen-Robineau L. TRAMIL ethnopharmacological survey: knowledge distribution of medicinal plant use in the southeast region of Puerto Rico. P R Health Sci J. 2009;28(4):329-39.

6. Sabitha GS A, Patnaik S. Costus speciosus, an antidiabetic plant -review. FS J Pharm Res. 2012;1(3):52-3.

7. Eliza J, Daisy P, Ignacimuthu S. Antioxidant activity of costunolide and eremanthin isolated from Costus speciosus (Koen ex. Retz) Sm. Chem Biol Interact. 2010;188(3):467-72.

8. Eliza J, Daisy P, Ignacimuthu S, Duraipandiyan V. Antidiabetic and antilipidemic effect of eremanthin from Costus speciosus (Koen.)Sm., in STZ-induced diabetic rats. Chem Biol Interact. 2009;182(1):67-72.

9. Murugan S, Uma Devi P, Parameswari NK, Mani KR. Antimicrobial activity of Syzygium jambos against selected human pathogens. Int J Pharma Pharmaceut Sci. 2011;3(2):45-7.

10. Rezende WP, Borges LL, Alves NM, Ferri PH, Paula JR. Chemical variability in the essential oils from leaves of Syzygium jambos. Revista Brasileira de Farmacognosia 2013;23(3). http://dx.doi.org/10.1590/S0102$695 \times 2013005000035$.

11. Oliveira AC, Endringer DC, Amorim LA, das Gracas LBM, Coelho MM. Effect of the extracts and fractions of Baccharis trimera and Syzygium cumini on glycaemia of diabetic and non-diabetic mice. J Ethnopharmacol. 2005;102(3):465-9.

12. Djipa CD, Delmee M, Quetin-Leclercq J. Antimicrobial activity of bark extracts of Syzygium jambos (L.) alston (Myrtaceae). J Ethnopharmacol. 2000;71(1-2):307-13.

13. Reynertson KA, Yang H, Jiang B, Basile MJ, Kennelly EJ. Quantitative analysis of antiradical phenolic constituents from fourteen edible Myrtaceae fruits. Food Chem. 2008;109(4):883-90.

14. Aslan M, Deliorman Orhan D, Orhan N, Sezik E, Yesilada E. In vivo antidiabetic and antioxidant potential of Helichrysum plicatum ssp. plicatum capitulums in streptozotocin-induced-diabetic rats. J Ethnopharmacol. 2007;109(1):54-9.

15. Rauter AP, Martins A, Lopes R, Ferreira J, Serralheiro LM, Araujo ME, et al. Bioactivity studies and chemical profile of the antidiabetic plant Genista tenera. J Ethnopharmacol. 2009;122(2):384-93.

16. Kumar A, llavarasan $R$, Jayachandran $T$, Decaraman $M$, Aravindhan $P$, Padmanabhan N, et al. Phytochemicals Investigation on a Tropical Plant, Syzygium cumini from Kattuppalayam, Erode District, Tamil Nadu, South India. Pak J Nutr. 2009:8:83-5

17. Hernández-Soto RL-C, M.E, Díaz-Jiménez L, Villanueva-Ramírez S. Extracción y cuantificación indirecta de las saponinas de Agave lechuguilla Torrey. In: e-Gnosis. vol. 3; 2005; 1-9.

18. Su HC, Hung LM, Chen JK. Resveratrol, a red wine antioxidant, possesses an insulin-like effect in streptozotocin-induced diabetic rats. Am J Physiol Endocrinol Metab. 2006;290(6):E1339-1346.

19. Liu X, Kim JK, Li Y, Li J, Liu F, Chen X. Tannic acid stimulates glucose transport and inhibits adipocyte differentiation in 3 T3-L1 cells. J nutr. 2005;135(2):165-71.
20. Sivitz WI, Yorek MA. Mitochondrial dysfunction in diabetes: from molecular mechanisms to functional significance and therapeutic opportunities. Antioxidants Redox Signal. 2010;12(4):537-77.

21. Luciano-Montalvo C, Boulogne I, Gavillan-Suarez J. A screening for antimicrobial activities of Caribbean herbal remedies. BMC Complement Altern Med. 2013:13:126.

22. Bladt WRS. Plant Drug Analysis. In: Plant drug analysis: A Thin Layer Chromatography Atlas. 2nd ed. Berlin, Germany: Springer Dordrecht Heidelberg; 2009.

23. Majaw S, Moirangthem J. Qualitative and Quantitative Analysis of Clerodendron colebrookianum Walp. Leaves and Zingiber cassumunar Roxb. Rhizomes. Ethnobotanical Leaflets. 2009;2009(5):3. Available at: http:// opensiuc.lib.siu.edu/ebl/vol2009/iss5/3

24. Hamuel DJ. Phytochemicals: Extraction Methods, Basic Structures and Mode of Action as Potential Chemotherapeutic Agents. In: Rao DV, editor. Phytochemicals - A Global Perspective of Their Role in Nutrition and Health. 2012.

25. Pourmorad F, Hosseinimehr SJ, Shahabimajd N. Antioxidant activity, phenol and flavonoid contents of some selected Iranian medicinal plants. Afr J Biotechnol. 2006;5(11):1142-5.

26. Shamsa F, Hamidreza M, Rouhollah G, Mohammadreza V. Spectrophotometric determination of total alkaloids in some Iranian medicinal plants. Thai J Pharm Sci. 2008;32:17-20.

27. AKEaY SA. Phytochemical screening of three medicinal plants: Neem leaf (Azadirachta indica), Hibiscus leaf (Hibiscus rosa-sinensis) and Spear grass leaf (Imperata cylindrica). Continental J Pharmaceut Sci. 2010;4:47-50.

28. Ncube B, Ngunge VN, Finnie JF, Van Staden J. A comparative study of the antimicrobial and phytochemical properties between outdoor grown and micropropagated Tulbaghia violacea Harv. plants. J Ethnopharmacol. 2011;134(3):775-80.

29. Keller AC, Vandebroek I, Liu Y, Balick MJ, Kronenberg F, Kennelly EJ, et al. Costus spicatus tea failed to improve diabetic progression in C57BLKS/J db/ $\mathrm{db}$ mice, a model of type 2 diabetes mellitus. J Ethnopharmacol. 2009;121(2):248-54.

30. Buchanan J, Mazumder PK, Hu P, Chakrabarti G, Roberts MW, Yun UJ, et al. Reduced cardiac efficiency and altered substrate metabolism precedes the onset of hyperglycemia and contractile dysfunction in two mouse models of insulin resistance and obesity. Endocrinology. 2005;146(12):5341-9.

31. Germosén-Robineau LDM, García-González M, Herrera J, Morón F, Sáenz-Campos D, Solís P. Farmacopea Vegetal Caribeña. 2dath ed. León, Nic: Editorial Universitaria, UNAN-León; 2005.

32. National Institutes of Health National Center for Complementary and Integrative Health Policy. NCCIH Policy: Natural Product Integrity. 2015

33. International Diabetes Federation. IDF Diabetes Atlas. 6th ed. Brussels, Belgium: International Diabetes Federation; 2013.

34. Ekoé J-M, Zimmet P, Williams R, editors. The Epidemiology of Diabetes Mellitus: An International Perspective. Chichester: John Wiley; 2001.

35. Evgeny T. Denisov IBAe. Oxidation and Antioxidants in Organic Chemistry and Biology. Boca Raton, Florida, USA, CRC Press; 2005.

36. Korkina LG, Afanas'ev IB. Antioxidant and chelating properties of flavonoids. Adv Pharmacol. 1997;38:151-63.

37. Johansen JS, Harris AK, Rychly DJ, Ergul A. Oxidative stress and the use of antioxidants in diabetes: linking basic science to clinical practice. Cardiovasc Diabetol. 2005;4(1):5.

38. Jakhetia V, Patel R, Khatri P, Pahuja N, Garg S, Pandey A, et al. Cinnamon: a pharmacological review. J Adv Sci Res. 2010;1 (2):19-23.

39. Teixeira CC, Fuchs FD, Blotta RM, Knijnik J, Delgado IC, Netto MS, et al. Effect of tea prepared from leaves of Syzygium jambos on glucose tolerance in nondiabetic subjects. Diabetes Care. 1990;13(8):907-8.

40. Teixeira CC, Weinert LS, Barbosa DC, Ricken C, Esteves JF, Fuchs FD. Syzygium cumini (L.) Skeels in the treatment of type 2 diabetes: results of a randomized, double-blind, double-dummy, controlled trial. Diabetes Care. 2004;27(12):3019-20.

41. Srivastava S, Chandra D. Pharmacological potentials of Syzygium cumini: a review. J Sci Food Agric. 2013;93(9):2084-93.

42. Brahmachari G. Bio-flavonoids with promising anti-diabetic potentials: A critical survey. In: Tiwari VK MB, editor. Opportunity, Challenge and Scope of Natural Products in Medicinal Chemistry. Kerala, India: Research Signpost; 2011. p. 187-212.

43. Hung HY, Qian K, Morris-Natschke SL, Hsu CS, Lee KH. Recent discovery of plant-derived anti-diabetic natural products. Nat Prod Rep. 2012;29(5):580-606. 
44. Jothivel NPS, Appachi M, Singaravel S, Rasilingam D, Deivasigamani K, Thangavel S. Anti-diabetic activity of methanol leaf extract of Costus pictus D. Don in alloxan-induced diabetic rats. J Heal Sci. 2007;53(6):655-63.

45. Mosihuzzaman M, Nahar N, Ali L, Rokeya B, Khan AK, Nur EAM, et al. Hypoglycemic effects of three plants from eastern Himalayan belt. Diabetes Res. 1994;26(3):127-38.

46. Rajesh MSHMS, Sathyaprakash RJ, Raghuram Shetty A, Shivananda TN. Antihyperglycemic activity of the various extracts of Costus speciosus rhizomes. J Nat Remedies. 2009;9(2):235-41.

47. Pratley RE WC, Bogardus C. Metabolic abnormalities in the development of type 2 diabetes mellitus. In: LeRoith DTS, Olefsky JM, editors. Diabetes Mellitus: A Fundamental and Clinical Text. 2nd ed. Philadelphia: Lippincott Williams \& Wilkins; 1999. p. 548-57.

48. Coleman DL. Effects of parabiosis of obese with diabetes and normal mice. Diabetologia. 1973;9(4):294-8.

49. Coleman DL. A historical perspective on leptin. Nat Med. 2010;16(10):1097-9.

50. Mazumder PK, O'Neill BT, Roberts MW, Buchanan J, Yun UJ, Cooksey RC, et al. Impaired cardiac efficiency and increased fatty acid oxidation in insulinresistant ob/ob mouse hearts. Diabetes. 2004;53(9):2366-74.

51. Genuth SM, Przybylski RJ, Rosenberg DM. Insulin resistance in genetically obese, hyperglycemic mice. Endocrinology. 1971;88(5):1230-8.

52. Stanely Mainzen Prince P, Kamalakkannan N, Menon VP. Syzigium cumini seed extracts reduce tissue damage in diabetic rat brain. J Ethnopharmacol. 2003;84(2-3):205-9.

53. World Health Organization. General Guidelines for Methodologies on Research and Evaluation of Traditional Medicine. In. Geneva; 2000: 1-73.

54. Chou TC. Drug combination studies and their synergy quantification using the Chou-Talalay method. Cancer Res. 2010;70(2):440-6.

55. Prabhakar PK, Doble M. Effect of Natural Products on Commercial Oral Antidiabetic Drugs in Enhancing 2-Deoxyglucose Uptake by 3 T3-L1 Adipocytes. Ther Adv Endocrinol Metab. 2011;2(3):103-14.

56. Prabhakar PK, Kumar A, Doble M. Combination therapy: a new strategy to manage diabetes and its complications. Phytomedicine. 2014;21(2):123-30.

\section{Submit your next manuscript to BioMed Central and take full advantage of:}

- Convenient online submission

- Thorough peer review

- No space constraints or color figure charges

- Immediate publication on acceptance

- Inclusion in PubMed, CAS, Scopus and Google Scholar

- Research which is freely available for redistribution 